Article

\title{
Comparing Two Operating Configurations in a Full-Scale Arsenic Removal Plant. Case Study: Guatemala
}

\author{
Sofía E. Garrido Hoyos ${ }^{1}{ }^{1 *}$, Martha Avilés Flores ${ }^{1}$, A. Ramírez Gonzalez ${ }^{1}$, \\ Celia Grajeda Fajardo ${ }^{2}$, Saúl Cardoso Zoloeta ${ }^{2}$ and Hayron Velásquez Orozco ${ }^{3}$
}

1 Water Treatment and Quality Department, Mexican Institute of Water Technology (IMTA), Paseo Cuauhnáhuac 8532, Col Progreso, Jiutepec C.P.62550, Mexico; E-Mails: maviles@tlaloc.imta.mx (M.A.F.); tramirez@tlaloc.imta.mx (A.R.G.)

2 Río Azul Company, 16 Calle 9-60, Condado El Naranjo, Mixco, Guatemala; E-Mails: cgrajeda@condadonaranjo.com (C.G.F.); cardoso@condadonaranjo.com (S.C.Z.)

3 ECO-TEC Company, Carretera a El Salvador km 26.5. Cruce a Santa Elena Barilas, Guatemala City, Guatemala; E-Mail: hvelasquez@ecotec-centroamerica.com

* Author to whom correspondence should be addressed; E-Mail: sgarrido@tlaloc.imta.mx; Tel.: +52-777-329-3662; Fax: +52-777-319-4381.

Received: 10 April 2013; in revised form: 24 May 2013 / Accepted: 29 May 2013 /

Published: 21 June 2013

\begin{abstract}
The present study was conducted in Naranjo County located in the municipality of Mixco, Guatemala. The water supply source comes from two wells with a maximum flow of 25.24 and $33.44 \mathrm{~L} \cdot \mathrm{s}^{-1}$. The main problem with this source is the high arsenic concentration - between 0.1341 and $0.1671 \mathrm{mg} \cdot \mathrm{L}^{-1}$. The aim of this study was to conduct laboratory tests, basic engineering and supervision of the construction and evaluation of an operations plant using two configurations, A (low-rate sedimentation and ceramic filter) and $\mathrm{B}$ (high-rate sedimentation and clinoptilolite filter), to remove arsenic present in water for human use and consumption. This plant supplies water to Naranjo County in Mixco, Guatemala (5000 inhabitants). First, a laboratory Jar Test was performed to evaluate arsenic removal efficiency. And second, a conventional clarification plant was then built (design flow: $25.24 \mathrm{~L} \cdot \mathrm{s}^{-1}$ ). The best results were achieved with configuration $\mathrm{B}$, with the following reagents and dosage as defined by the laboratory tests: $10 \mathrm{mg} \mathrm{L}^{-1}$ ferric chloride as coagulant; $1.8 \mathrm{mg} \cdot \mathrm{L}^{-1} \mathrm{CH}$-polyfocal as flocculant and $0.4 \mathrm{mg} \mathrm{L}{ }^{-1}$ MIT03 as color removal; $1 \mathrm{mg} \mathrm{L}^{-1}$ sodium hypochlorite as oxidant and adjusting $\mathrm{pH}$ to $\approx 7.0$ with sodium hydroxide. Once the plant began operating, the efficiency of the treatment process was evaluated. The maximum elimination efficiencies were obtained $100 \%$ for turbidity
\end{abstract}


(0 UTN), 89.54\% (3.66 UPt-Co) for color and 96.80\% (0.005 $\left.\mathrm{mg} \mathrm{L}^{-1}\right)$ for arsenic, values that comply with Guatemalan standards. For this case, the relation between Fe(III) dosage/mg and $\mathrm{As}(\mathrm{V})$ removal was 1:46.

Keywords: arsenic removal; media filters; treatment plant; water supply

\section{Introduction}

The natural origin of arsenic in groundwater is linked to the lithology of the geological materials that compose the aquifer and the oxidation-reduction processes that affect this element. Other origins are related to anthropogenic factors, such as the leaching of mine waste and the use of pesticides.

Toxicity from arsenic is well known and can occur in two ways: acute and chronic. Acute toxicity results from the ingestion of high concentrations of arsenic over a short period of time, whereas chronic toxicity is the result of the ingestion of small arsenic amounts over an extended period. Arsine is considered the most toxic form, followed by arsenite, arsenate, and organic compounds that contain this element [1].

Ingestion and inhalation are the main routes of exposure to arsenic in humans. Arsenic accumulates in the body due to chronic exposure, when exceeding certain concentration levels. It can cause infection (such as skin lesions), peripheral vascular diseases ("black foot" disease), respiratory illnesses, neurological (peripheral neuropathies) and cardiovascular diseases and different types of cancer (lung, kidney, liver, bladder and skin). Humans who ingest inorganic arsenic through water over long time periods can exhibit palmoplantar hyperkeratosis, which mainly manifests as skin pigmentation and callosities on the hands and feet [2]. This has generated growing interest in public health regarding chronic exposure to arsenic in water for human use and consumption.

More than 4 million people depend on water containing high concentrations of arsenic $\left(>0.05 \mathrm{mg} \mathrm{L}^{-1}\right)$ in Argentina, Chile, Bolivia, Peru, Ecuador and Mexico, where arsenic has natural or anthropic origins, such as mining activities [3]. In recent years, great importance has been given to arsenic in water for use and human consumption. To protect the public's health, the maximum permissible limit has decreased from 50 to $10 \mathrm{mg} \mathrm{L}^{-1}$ [4]. This influences treatment processes and the selection of alternatives to attain the best solution, which depends on numerous factors, such as: the size of the treatment device, arsenic concentration and distribution of species, chemical composition and degree of mineralization of raw water, guidelines for the residual arsenic concentration, economic constraints and investment, operations and maintenance concerns, among others [5].

Most methods for arsenic removal are effective, including: conventional clarification (coagulation-flocculation-sedimentation-filtration), activated alumina, ionic exchange, adsorption and capacitive deionization membranes [6-8]. Many authors have reported obtaining the best removal performance with $\mathrm{As}(\mathrm{V})$ than $\mathrm{As}(\mathrm{III})$; therefore arsenic can be pre-oxidized using chlorine and potassium permanganate as oxidizers [9].

The elimination of arsenic through conventional methods, using coagulants followed by filtration, is an effective process for the elimination of $\mathrm{As}(\mathrm{V})$. According to tests conducted in the laboratory and in pilot plants, it was determined that $\mathrm{FeCl}_{3} \cdot 6 \mathrm{H}_{2} \mathrm{O}$ as a coagulant is more efficient for eliminating arsenic 
than $\mathrm{Al}_{2}\left(\mathrm{SO}_{4}\right)_{3}-96 \%$ and $85 \%$, respectively. Ahmed [10] obtained $91 \%$ removal of As(V) with $\mathrm{FeCl}_{3}$ at a $\mathrm{pH}$ of 7 , an important factor that must be considered for water; there is greater solubility for iron salts at a $\mathrm{pH}$ of 6.5 to 7.5 and for aluminum sulphate at 6.0 to 6.5 [11-13].

Shen [9] compared the ability of $20 \mathrm{mg} \mathrm{L}^{-1}$ doses of alum, lime, ferrous sulfate and ferric chloride to remove arsenic from well water ( $\mathrm{pH} 6.8$ and $1.0 \mathrm{mg} \mathrm{L}^{-1}$ arsenic) in bench-scale tests, for which arsenic removals of $32 \%, 20 \%, 24 \%$ and $82 \%$ were achieved with the respective coagulants. Because As(III) is most likely to be found in anaerobic groundwater, it is likely that the well water treated in Shen's study contained As(III). Pre-treatment with chlorine-presumably oxidizing As(III) to $\mathrm{As}(\mathrm{V})$ - enhanced the ability of the ferric chloride to remove arsenic; Shen reported removals from $82.5 \%$ to approximately $100 \%$ with $50 \mathrm{mg} \mathrm{L}^{-1}$ (ratio $1: 50$ ).

In another bench-scale study, Gulledge and O'Connor [14] analyzed water spiked with As(V) and tested 10 to $50 \mathrm{mg} \mathrm{L}^{-1}$ alum and ferric sulfate at a $\mathrm{pH}$ of 5.0 to 8.0. The ferric sulfate achieved better removal than the alum (88.6\%-99.0\% versus $18.5 \%-93.6 \%)$ and was less sensitive to increases in $\mathrm{pH}$. Sorg and Logsdon [15] reported comparable findings in their pilot-scale study-i.e., significant removal of arsenic with conventional treatment and superior performance by the ferric coagulant. Similar results are also cited from an earlier bench-scale evaluation conducted by Logsdon et al. [16].

Additionally, the volume, handling and final disposal of generated wastes should be considered, since the previously-mentioned methods generate relatively high volumes of sludge contaminated with arsenic.

The aim of this study was to conduct treatability tests, basic engineering and supervision of the construction and evaluation of an operations plant with two configurations to remove arsenic present in water for human use and consumption. This plant supplies water to Naranjo County in Mixco, Guatemala.

\section{Experimental Section}

\subsection{Study Area}

The present study was conducted in Naranjo County, located in the municipality of Mixco, Guatemala (Figure 1), $29 \mathrm{~km}$ west of the capital city of Guatemala, with an elevation of roughly 1650 meter above sea level (m.a.s.l). It has a total population of 5000 inhabitants, according to the National Statistics Institute of Guatemala [17].

The water supply source comes from two wells (Well No. 1 and Well No. 2) with a maximum flow of 25.24 and $33.44 \mathrm{~L} \cdot \mathrm{s}^{-1}$, respectively.

\subsection{Water Quality}

Raw water from Wells No. 1 and No. 2 was analyzed according to parameters established by the Guatemalan standards for drinking water, COGUANOR NTG 29 001. Table 1 shows the values of some of the parameters analyzed.

The quality of the raw water complies with the standards, except for $\mathrm{pH}$ with a value of 6.61 (maximum acceptable limit $(\mathrm{MAL})=7.0-7.5)$ and total arsenic with values of $0.1341 \mathrm{mg} \mathrm{L^{-1 }}$ for Well No. 1 and $0.1671 \mathrm{mg} \mathrm{L}^{-1}$ for Well No. 2 (13 and 16 times above the standard value of $0.010 \mathrm{mg} \mathrm{L}^{-1}$, respectively). In addition, the water is considered to be moderately hard (75-150 $\left.\mathrm{mg} \mathrm{L}^{-1}\right)$. 
According to the speciation diagram for arsenic present in untreated water from Wells No. 1 and No. 2, the predominant species is the anionic forms $\mathrm{H}_{2} \mathrm{AsO}_{4}{ }^{-}$and $\mathrm{H}_{2} \mathrm{AsO}_{4}{ }^{2-}$ with oxidation state (V) (Figures 2 and 3). Cebrian [18] have reported the approximate ratio of As(III):As(V) in groundwater as 70:30.

Figure 1. Study area: Naranjo County, Mixco, Guatemala (NCMG).

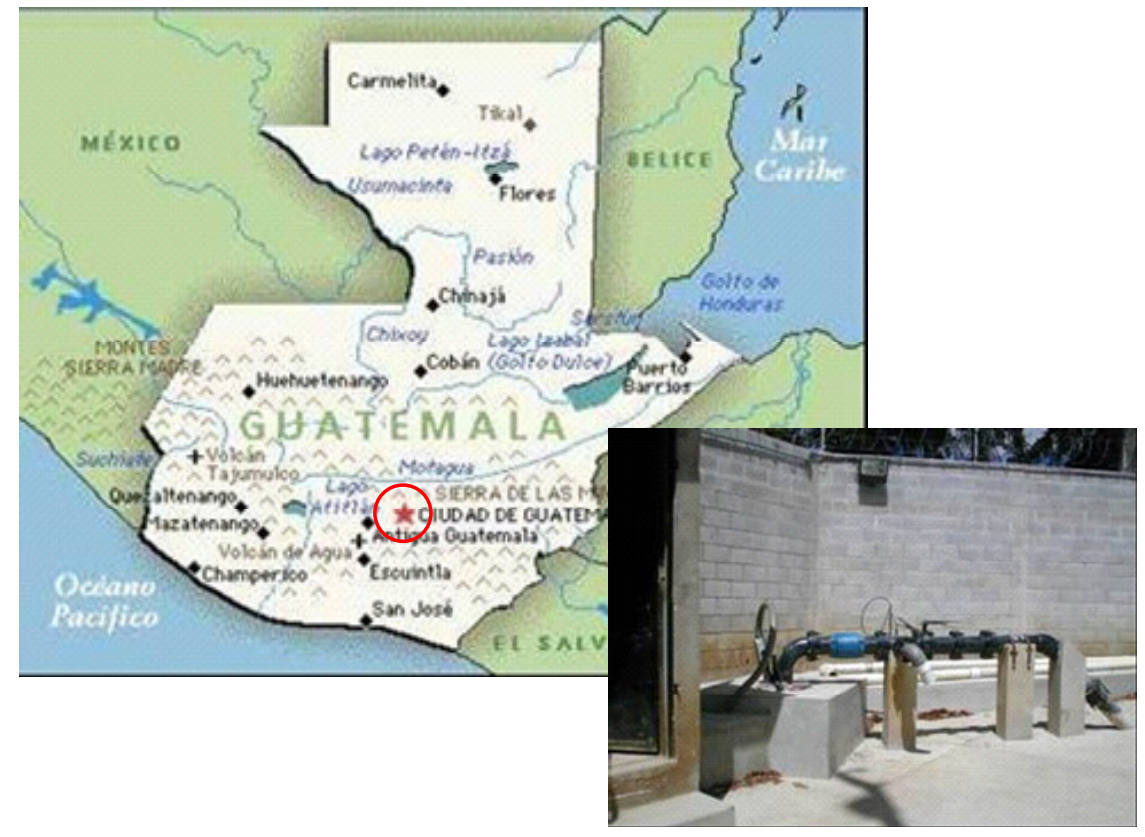

Table 1. Physicochemical characterization of raw water.

\begin{tabular}{|c|c|c|c|c|}
\hline \multirow{2}{*}{ Parameter } & \multirow{2}{*}{ Well No. 1} & \multirow{2}{*}{ Well No. 2} & \multicolumn{2}{|c|}{ COGUANOR NTG 29001} \\
\hline & & & MAL & MPL \\
\hline \multicolumn{5}{|l|}{ Physical } \\
\hline True Color (Pt-Co Units) & $<2.0$ & 10 & 5 & 35 \\
\hline Turbidity (NTU) & 0.09 & 20 & 5 & 15 \\
\hline Total dissolved solids ${ }^{1}$ & 206 & 233 & 500 & 1000 \\
\hline \multicolumn{5}{|l|}{ Chemical } \\
\hline $\mathrm{pH}$ & 6.61 & 7.14 & $7.0-7.5$ & $6.5-8.5$ \\
\hline Alkalinity ${ }^{1}$ & 128 & 134 & - & - \\
\hline Hardness $_{\text {total }}{ }^{1}\left(\mathrm{CaCO}_{3}\right)$ & 96.8 & 67.1 & 100 & 500 \\
\hline Chlorides ${ }^{1}$ & 5.54 & 3.02 & 100 & 250 \\
\hline Sulphates ${ }^{1}$ & 8.24 & 28 & 100 & 250 \\
\hline Nitrates ${ }^{1}$ & 1.023 & $<0.093$ & - & 10 \\
\hline Fluorides ${ }^{1}$ & 0.322 & 0.295 & - & 1.7 \\
\hline Iron $^{1}$ & $<0.05$ & $<0.05$ & 0.1 & 1.0 \\
\hline Manganese $^{1}$ & $<0.05$ & $<0.05$ & 0.05 & 0.5 \\
\hline Arsenic ${ }^{1}$ & 0.1341 & 0.1671 & - & 0.010 \\
\hline
\end{tabular}

Notes: ${ }^{1}$ Units in $\mathrm{mg} \mathrm{L}^{-1}$; MAL: Maximum acceptable limit; MPL: Maximum permissible limit. 
Figure 2. Eh-pH diagram for predominant arsenic species in equilibrium in raw water from Well No. 1 (Initial $0.134 \mathrm{mg} \mathrm{As} \cdot \mathrm{L}^{-1}$; $\mathrm{pH} 6.61$, Eh $0.16 \mathrm{~V}$ ) at $25^{\circ} \mathrm{C}$ and $1 \mathrm{~atm}$.

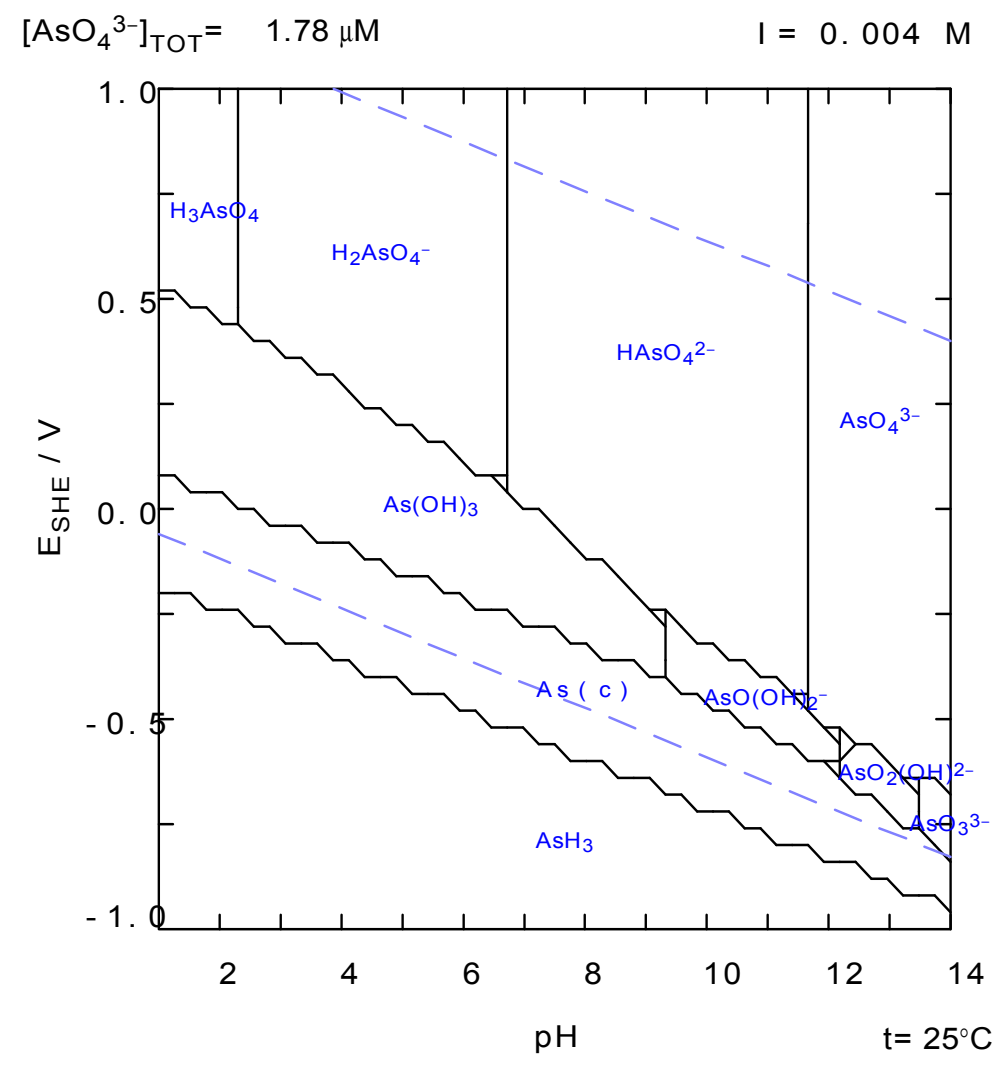

Figure 3. Eh-pH diagram for predominant arsenic species in equilibrium in raw water from Well No. 2 (Initial $0.167 \mathrm{mg} \mathrm{As} \cdot \mathrm{L}^{-1} ; \mathrm{pH} 7.14$, Eh $0.23 \mathrm{~V}$ ) at $25^{\circ} \mathrm{C}$ and $1 \mathrm{~atm}$.

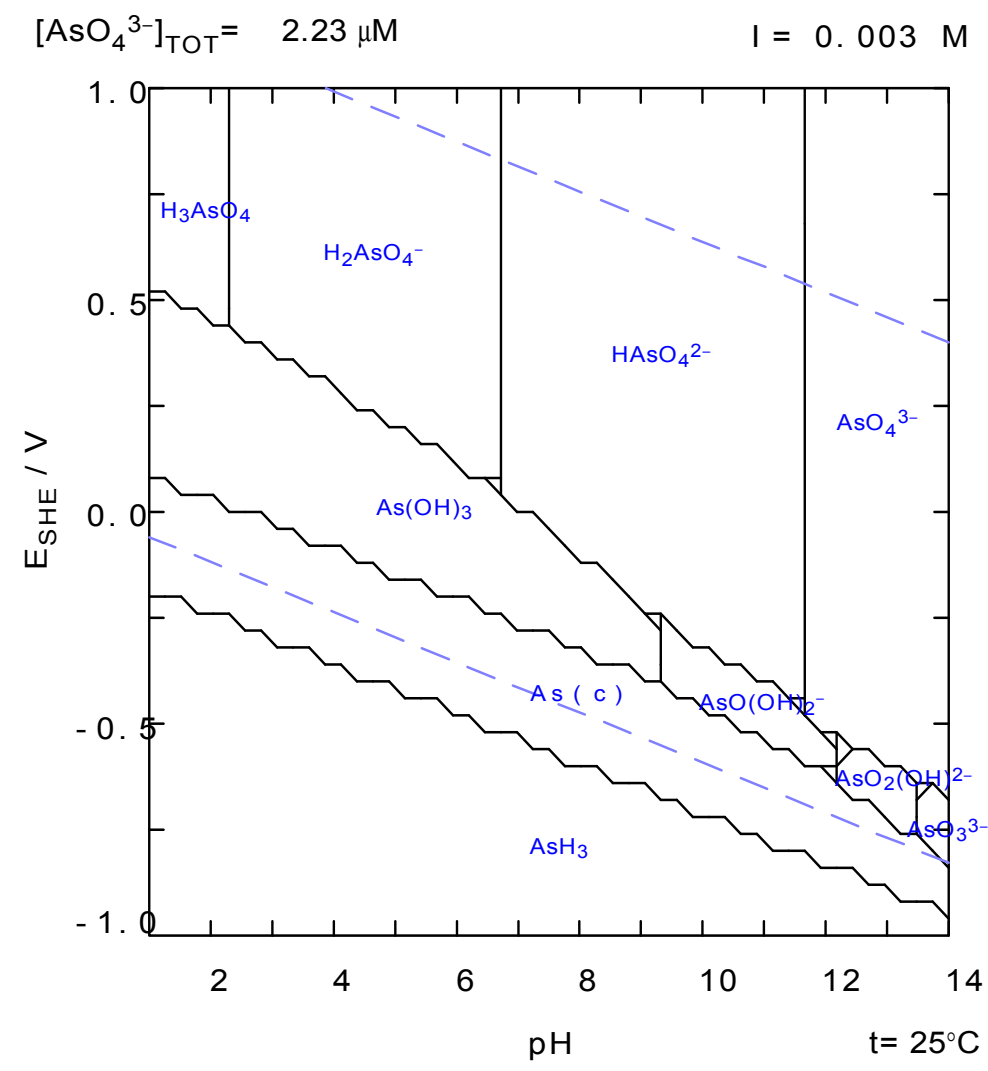




\subsection{Laboratory Tests}

A Jar Test was performed in the laboratory to evaluate arsenic removal efficiency. Five experiments were conducted with water from Well No. 1 (Table 2). Sodium hypochlorite $(\mathrm{NaOCl}-6 \%)$ was used as an oxidizing agent, with dosages of 0.5 and $1 \mathrm{mg} \mathrm{L}^{-1}$. Liquid ferric chloride $\left(\mathrm{FeCl}_{3} 40 \%\right)$ was used as a coagulant, with dosages of 4, 8, 12, 16 and $20 \mathrm{mg} \mathrm{L}^{-1}\left(24.7,49.3,74.0,98.6\right.$ and $123.3 \mu \mathrm{mol} \mathrm{Fe} \mathrm{L}^{3+} \mathrm{L}^{-1}$, respectively). Red clay was used to increase the turbidity, with an amount of 0.05 and $0.10 \mathrm{mg} \cdot \mathrm{L}^{-1}$ and $\mathrm{pH}$ was regulated with $\mathrm{NaOH}$ or $\mathrm{HCl} 0.1 \mathrm{~N}$, depending on the case. The Jar Test operation was conducted according to ASTM D 2035-80 (ASTM Committee, 1995) [19]; the test's operating conditions are shown in Table 3. The floc size was determined according to Willcomb's Index and the Water Research Institute of England [20].

In the preliminary laboratory experiments, the flocs were removed by filtration through $0.45 \mu \mathrm{m}$ membrane filters, which is a very efficient solid/liquid phase separation technique. In order to follow-up on simulation processes for coagulation, flocculation and sedimentation, physical determinations were made, such as temperature, turbidity and apparent color; chemical determinations included $\mathrm{pH}$, iron and total arsenic.

Table 2. Configuration of Jar Test experiments.

\begin{tabular}{cccc}
\hline \multirow{2}{*}{ Experiment No. } & \multirow{2}{*}{ pH Adjustment } & \multicolumn{2}{c}{ Dose $\left(\mathrm{mg} \mathrm{L}^{\mathbf{- 1}}\right)$} \\
\cline { 3 - 4 } & & NaOCl & Clay \\
\hline 1 & 6.2 to 7 & 1.0 & - \\
2 & None & 0.5 & - \\
3 & 6.5 & 1.0 & 0.10 \\
4 & None & 0.5 & 0.05 \\
5 & None & 0.5 & 0.10 \\
\hline
\end{tabular}

Table 3. Jar Test operating conditions.

\begin{tabular}{cccc}
\hline Process & Mixer $(\mathbf{r p m})$ & Time & Gradient $\left(\mathbf{s}^{-\mathbf{1}}\right)$ \\
\hline Fast mixing & 300 & $5-15 \mathrm{~s}$ & 600 \\
Flocculation & & $(\mathrm{min})$ & \\
First stage & 70 & 5 & 80 \\
Second stage & 60 & 5 & 60 \\
Third stage & 44 & 5 & 40 \\
Fourth stage & 33 & 5 & 27 \\
Sedimentation & 0 & 15 & - \\
\hline
\end{tabular}

\subsection{Full-Scale Water Plant}

The optimum values obtained by laboratory tests were used to design and build a conventional clarification plant in NCMG for arsenic removal from Wells No. 1 and No. 2. The design flow is $25.24 \mathrm{~L} \cdot \mathrm{s}^{-1}$. This plant has the following units: pre-oxidation, regulation of $\mathrm{pH}$, one fast mix unit, four flocculators, two sedimentation basins, four pressure filter units, and finally, treated water is disinfected with hypochloride sodium and stored in two $1000 \mathrm{~m}^{3}$ tanks. Figure 4 shows a diagram of the processing units at the arsenic removal plant. 
Figure 4. Flow diagram of the arsenic removal plant, Mixco, Guatemala.

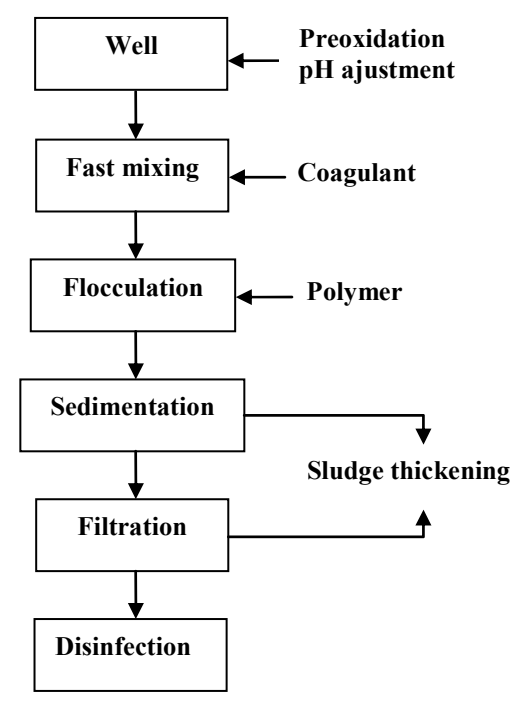

Table 4 shows the operating conditions for the units with the two filter media configurations: (A) Microlite-KINETICO ${ }^{\circledR}$ - a synthetic ceramic media [21] and (B) TurbidexTM-clinoptilolite zeolite/potassium, calcium and sodium aluminosilicate. The sedimentation basin for the ceramic filter media did not contain laminar flow devices, whereas for the clinoptilolite filter media there were laminar flow devices. Table 5 shows the physical characteristics for both filter media. In addition, configuration (A) contained raw water from Well No. 1 (pre-oxidation $2.7 \mathrm{mg} \cdot \mathrm{L}^{-1}$ ) and configuration (B) contained raw water from Wells No. 1 and No. 2 (pre-oxidation $4.95 \mathrm{mg} \cdot \mathrm{L}^{-1}$ ).

Table 4. Operating conditions of the two configurations.

\begin{tabular}{|c|c|c|}
\hline Process Unit & Ceramic Filter Configuration (A) & Clinoptilolite Filter Configuration (B) \\
\hline Pre-oxidation & $\mathrm{NaOCl}: 2.7 \mathrm{mg} \mathrm{L}^{-1}$ & $\mathrm{NaOCl}: 4.95 \mathrm{mg} \mathrm{L}^{-1}$ \\
\hline Coagulation & $\begin{array}{l}\mathrm{NaOH}: 22.78 \mathrm{mg} \mathrm{L} \\
\mathrm{FeCl}_{3}: 12 \mathrm{mg} \mathrm{L}-1\left(74 \mu \mathrm{mol} \cdot \mathrm{L}^{-1}\right) \\
\text { Poliflocal-CH: } 1.0 \mathrm{mg} \mathrm{L}^{-1} \\
\text { Velocity gradient, } \mathrm{G}: 1198 \mathrm{~s}^{-1} \\
\text { pH coagulation: } 7.23 \\
\text { Hydraulic detention time, } \mathrm{t}: 10 \mathrm{~s}\end{array}$ & $\begin{array}{l}\mathrm{NaOH}: 13.90 \mathrm{mg} \mathrm{L}^{-1} \\
\mathrm{FeCl}_{3}: 10 \mathrm{mg} \mathrm{L}-1\left(61.7 \mu \mathrm{mol} \cdot \mathrm{L}^{-1}\right) \\
\text { Poliflocal-CH: } 1.8 \mathrm{mg} \mathrm{L}^{-1} \\
\text { MIT03: } 0.4 \mathrm{mg} \mathrm{L}^{-1} \\
\text { G: } 1198 \mathrm{~s}^{-1} \\
\text { pH coagulation: } 6.98 \\
\text { t: } 10 \mathrm{~s}\end{array}$ \\
\hline Flocculation & $\begin{array}{l}\text { G: } 200-38-26-9 \mathrm{~s}^{-1} \\
\text { Hydraulic detention time, } \mathrm{t}: 20.73 \mathrm{~min}\end{array}$ & $\begin{array}{l}\mathrm{G}: 187-65-27-7 \mathrm{~s}^{-1} \\
\mathrm{t}: 20.73 \mathrm{~min}\end{array}$ \\
\hline Sedimentation & $\begin{array}{l}\text { Without laminar-flow devices. } \\
\text { Surface loading rate, SLR: } 72.2 \mathrm{~m}^{3} \cdot \mathrm{m}^{-2} \cdot \mathrm{d}^{-1} \\
\text { Weir loading rate: } 199.71 \mathrm{~m}^{3} \cdot \mathrm{m}^{-1} \cdot \mathrm{day}^{-1} \\
\text { Hydraulic detention time, } \mathrm{t}: 30.51 \mathrm{~min} \\
\end{array}$ & $\begin{array}{l}\text { With laminar-flow devices } \\
\text { SRL: } 150 \mathrm{~m}^{3} \cdot \mathrm{m}^{-2} \cdot \text { day }^{-1} \\
\text { Weir loading rate }: 316.97 \mathrm{~m}^{3} \cdot \mathrm{m}^{-1} \cdot \text { day }^{-1} \\
\mathrm{t}: 30.51 \mathrm{~min}\end{array}$ \\
\hline $\begin{array}{l}\text { Filtration } \\
\text { Pressure filters }\end{array}$ & $\begin{array}{l}\text { Ceramic media } \\
\text { Area, A: } 0.899 \mathrm{~m}^{2} \\
\text { Flow for each filter, Q: } 6.31 \mathrm{~L} \cdot \mathrm{s}^{-1} \\
\text { Hydraulic loading rate, } \mathrm{v}: 25.27 \mathrm{~m}^{3} \cdot \mathrm{m}^{-2} \cdot \mathrm{h}^{-1} \\
\text { Contact time, } \mathrm{t}: 2.12 \mathrm{~min} \\
\text { Backwash rate, } \mathrm{U}_{\mathrm{b}}: 18.95 \mathrm{~m}^{3} \cdot \mathrm{m}^{-2} \cdot \mathrm{h}^{-1}\end{array}$ & $\begin{array}{l}\text { Clinoptilolite media } \\
\text { Area, A: } 0.899 \mathrm{~m}^{2} \\
\text { Q: } 5.89 \mathrm{~L} \cdot \mathrm{s}^{-1} \\
\text { v: } 23.59 \mathrm{~m}^{3} \cdot \mathrm{m}^{-2} \cdot \mathrm{h}^{-1} \\
\mathrm{t}: 2.12 \mathrm{~min} \\
\mathrm{U}_{\mathrm{b}}: 16.42 \mathrm{~m}^{3} \cdot \mathrm{m}^{-2} \cdot \mathrm{h}^{-1}\end{array}$ \\
\hline
\end{tabular}


Table 5. Physical characteristics of media.

\begin{tabular}{ccccc}
\hline \multirow{3}{*}{ Media } & \multicolumn{4}{c}{ Physical Characteristics } \\
\cline { 2 - 5 } & $\begin{array}{c}\text { Surface Area } \\
\left(\mathbf{m}^{\mathbf{2}} \mathbf{g}^{-\mathbf{}}\right)\end{array}$ & $\begin{array}{c}\text { Particle Size } \\
(\mathbf{m m})\end{array}$ & $\begin{array}{c}\text { Uniformity } \\
\text { Coefficient }\end{array}$ & $\begin{array}{c}\text { Bed Depth } \\
(\mathbf{m})\end{array}$ \\
\hline Ceramic & $5-14$ & $0.25-0.43$ & 1.50 & 0.86 \\
Clinoptilolite & $14-25$ & $0.6-1.40$ & 1.64 & 0.85 \\
\hline
\end{tabular}

The dimensional layout took into account the purposes, performance and final dimensions of the units that compose the arsenic removal plant, as well as the geometry, extension and topography of the terrain and the existing infrastructure to be included in the plant. In particular, the layout was determined based on the following criteria:

(a) Existing infrastructure was considered, such as the water transportation system from the wells to the tanks, filters (included ceramic media) and pumping, and the water treatment plant's electromechanical equipment located in NCMG.

(b) The topographic slope was used for gravity flow, as well as to save energy and avoid the use of pumping equipment and prevent large volumes of soil movement.

(c) It was attempted to avoid separation between structures so as to reduce the length of the interconnection lines (as well as hydraulic head loss), leaving enough space for the installation of piping, meters, platforms and access stairs to elevated structures.

(d) The pipes were situated in order to not unnecessarily increase their lengths and so that deflections, due to changes in direction, corresponded to angles for which special commercial parts are available.

(e) Treated water from the arsenic removal plant was directed toward the property's low area, from where it flowed by gravity to four storage cisterns.

(f) A booth was situated for the placement of $\mathrm{pH}$ control panels, dispensers for sodium hydroxide, ferric chloride and polymer, and variable-frequency drives to set the rotational speed of the agitators to fast and slow mixing.

During the days on which the plant evaluation was conducted, the necessary adjustments for good operations were made, and so variations were observed in the values obtained for the different control parameters, including: temperature, turbidity, apparent color, $\mathrm{pH}$, iron and total arsenic.

\subsection{Analytical Methods}

The quality of raw water from Wells No. 1 and No. 2 and treated water was analyzed according to Standard Methods [22] and Hach methods [23].

Total arsenic was determined using two methods: the Wagtech Arsenator ${ }^{\circledR}$ field kit (London, UK) and atomic absorption spectrophotometer (AAS) to verify arsenic values from the field kit. The Wagtech Arsenator field kit uses a battery-operated handheld photometer to read the color stain, for better accuracy and precision. This kit continues to be used by UNICEF to test wells in Bangladesh [24]. It is the lowest cost and most portable and accurate method to determine safe limits of arsenic (WHO guidelines: $0.010 \mathrm{mg} \cdot \mathrm{L}^{-1}$ ). The AAS used was the Perkin Elmer Model 3100, equipped with a Perkin 
Elmer Model MHF-10 hydride generator (IMTA, Jiutepec, Mexico). The line source was an arsenic electrodeless discharge lamp at $193.7 \mathrm{~nm}$.

\section{Results and Discussion}

\subsection{Laboratory Test}

\subsubsection{Optimum Dose}

Average temperature among the five experiments varied slightly, from 24 to $26^{\circ} \mathrm{C}$. Figure 5 shows the effect of the dosage of ferric chloride on arsenic removal, with an initial arsenic concentration of $0.11-0.120 \mathrm{mg} \cdot \mathrm{L}^{-1}$. A trend can be observed, in which the higher the dosage of the coagulant, the lower the concentration of total arsenic in the treated water. Nevertheless, the variation in the percentage of arsenic removal with a dosage of 12 to $20 \mathrm{mg} \cdot \mathrm{L}^{-1}$ is not significant.

Figure 5. Influence of $\mathrm{FeCl}_{3} 6 \mathrm{H}_{2} \mathrm{O}$ dosage on total arsenic removal. Initial arsenic concentration $0.11-0.12 \mathrm{mg} \cdot \mathrm{L}^{-1}(n=3)$.

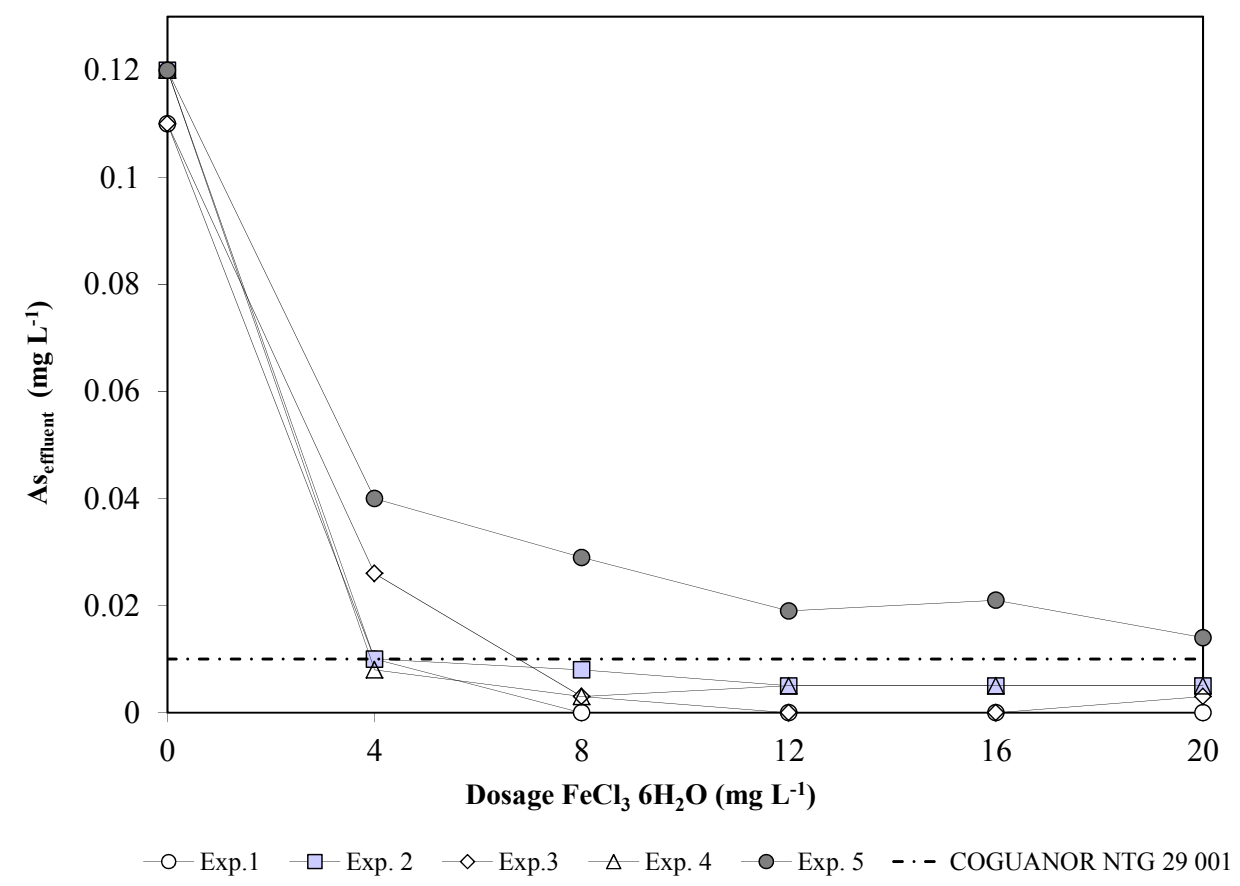

Previous studies have shown that the percentage of arsenic removed using alum and ferric chloride coagulation is independent of initial arsenic (V) concentration for a wide range of conditions. Scott [25] showed nearly constant arsenic removal percentages, 82\%-96\%, when using 3-10 $\mathrm{mg} \cdot \mathrm{L}^{-1}$ ferric chloride. Cheng [26] also showed nearly constant arsenic removal percentages while varying the initial arsenic (V) concentration from 0.0022 to $0.128 \mathrm{mg} \cdot \mathrm{L}^{-1}$ and treating with $20 \mathrm{mg} \mathrm{L}{ }^{-1}$ alum and $30 \mathrm{mg} \cdot \mathrm{L}^{-1}$ ferric chloride. Hearing [27] reported comparable findings, in which arsenic removal percentages remained nearly constant with $4.9 \mathrm{mg} \cdot \mathrm{L}^{-1}$ ferric chloride and raw arsenic concentration varying from 0.002 to $0.100 \mathrm{mg} \cdot \mathrm{L}^{-1}$.

The experiments that obtained the best arsenic removal results were 3 and 5 -with and without $\mathrm{pH}$ adjustment, respectively, and the addition of clay of $0.1 \mathrm{mg} \mathrm{L}^{-1}$. Removal values obtained with 12 and 
$20 \mathrm{mg} \cdot \mathrm{L}^{-1}$ dosages were $90.91 \%$ and $88.18 \%$ for experiment $3 \%$ and $84.17 \%$ and $88.33 \%$ for experiment 5, respectively (Figure 6). Arsenic and iron concentration in the treated water for all the experiments comply with Guatemalan standard COGUANOR NTG 29001.

Figure 6. Total arsenic removal percentage for different ferric chloride dosages.

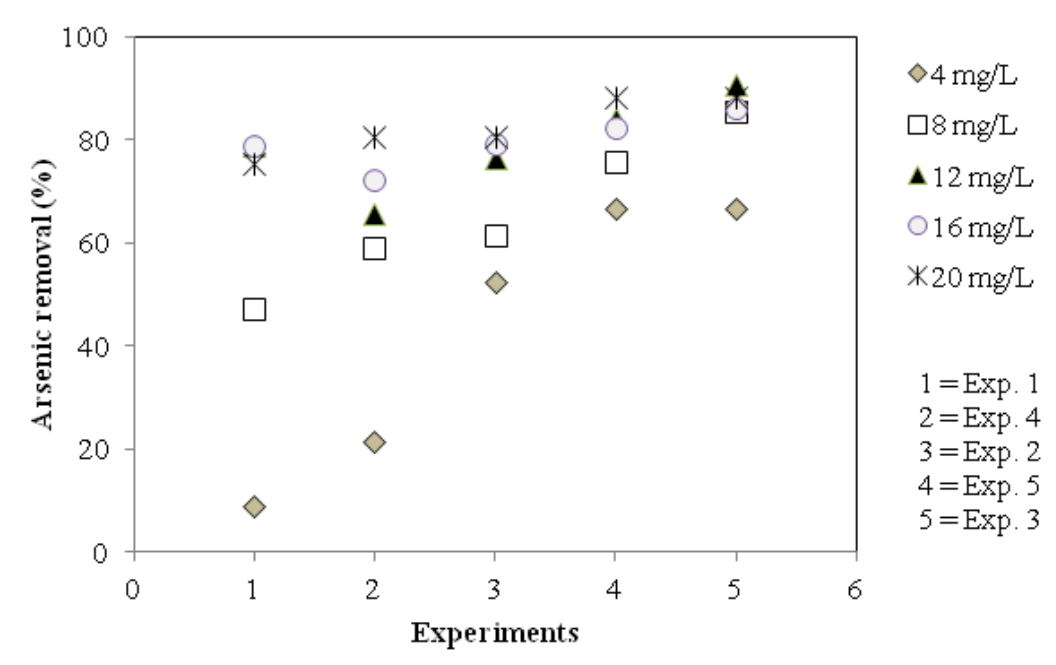

In all experiments, $100 \%$ turbidity removal was obtained with all dosages $\left(4-20 \mathrm{mg} \mathrm{\textrm {L } ^ { - 1 }}\right)$. The apparent color of treated water was reduced for concentrations of $12-20 \mathrm{mg} \mathrm{L}^{-1}$, and values of $2 \mathrm{Pt}-\mathrm{Co}$ units were obtained for experiment 3. This color behavior is related to the coagulation-flocculation process for dosages $>12 \mathrm{mg} \mathrm{L}^{-1}$; destabilization is achieved by adsorption and neutralization of charges. In addition, a sweeping mechanism can occur, in which the floc precipitates, removing the water's color and thereby making the process more efficient. Other important factors in color removal were pre-oxidation and the addition of clay to increase colloid concentration and interparticle contact (experiments 3-5).

\subsubsection{Qualitative Evaluation (Floc Size and Formation Time)}

Floc size was determined by Willcomb's Index and with the comparator developed by the Water Research Institute of England [20]. For low dosages of 4-8 $\mathrm{mg} \cdot \mathrm{L}^{-1}$, Willcomb's index varied between 2 and 6 , the flocs were dispersed and small. With dosages of $12-20 \mathrm{mg} \cdot \mathrm{L}^{-1}$, the flocs were relatively large, good and easily precipitated (Willcomb's Index 6 and 8). Experiment 5 showed larger flocs, between 1.5 and $2.25 \mathrm{~mm}$, with floc formation times of less than $100 \mathrm{~s}$ (Figure 7). 
Figure 7. Influence of $\mathrm{FeCl}_{3} \cdot 6 \mathrm{H}_{2} \mathrm{O}$ dosage on initial floc formation time in flocculation: $\operatorname{Exp} 2,4$ and $5(n=3)$.

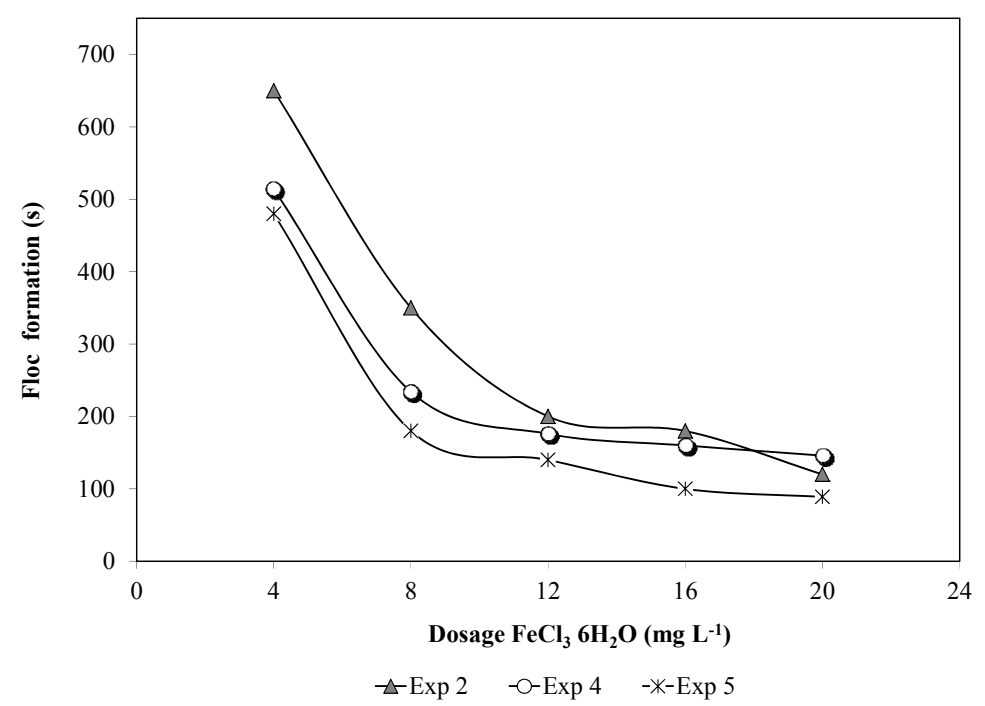

\subsubsection{Optimum $\mathrm{pH}$}

In primary laboratory test, the best results were obtained in the range of $10-20 \mathrm{mg} \cdot \mathrm{L}^{-1}$ ferric chloride dosage $(84.55 \%)$ and $\mathrm{pH}$ between 6.0 and 7.0 , that is fit with the $\mathrm{pH}$ of untreated water for the two wells, and on the other hand the predominant anionic species of arsenic were presented at this $\mathrm{pH}$ (Figures 2 and 3).

The best results were obtained for experiments 3 and 5 (adding clay, with and without $\mathrm{pH}$ adjustment and with a ferric chloride dosage of $12 \mathrm{mg} \cdot \mathrm{L}^{-1}$ ) with an arsenic removal of $90.91 \%$ and $84.17 \%$ and $\mathrm{pH}$ values of 6.51 and 6.54 , respectively, which comply with the Guatemala Standards. Studies conducted by Ahmed [10] on the influence of $\mathrm{pH}$ on coagulation with ferric chloride (200 $\mathrm{mg} \cdot \mathrm{L}^{-1}$ dosage) found that $91 \%$ of arsenic is removed $(\mathrm{V})$ at a $\mathrm{pH}$ between 6.0 and 7.0 .

Although the $\mathrm{pH}$ value of water has a large influence on arsenic removal if a wide $\mathrm{pH}$ range is examined, the effect of $\mathrm{pH}$ on arsenic removal under more realistic conditions is not that significant [28]. Figure 8 shows an evolution of the $\mathrm{pH}$ with arsenic removal for a ferric dosage of $12 \mathrm{mg} \cdot \mathrm{L}^{-1}$, were at higher $\mathrm{pH} 6.6$ it is not a significance arsenic removal $\approx 80 \%$.

Figure 8. $\mathrm{pH}$ Variation for $12 \mathrm{mg} \cdot \mathrm{L}^{-1}$ of $\mathrm{FeCl}_{3} 6 \mathrm{H}_{2} \mathrm{O}$ dosage.

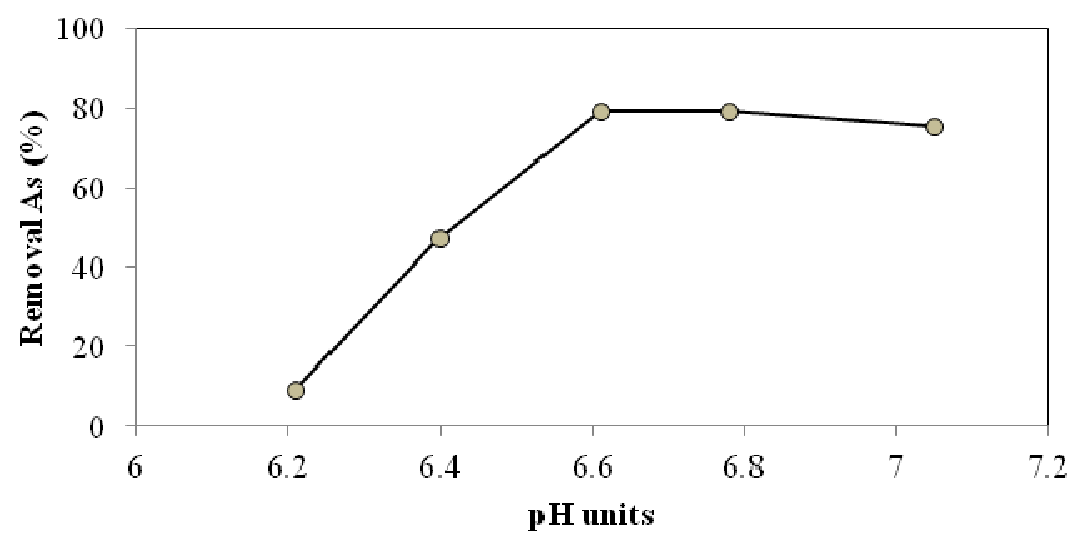




\subsection{Evaluation of Plant Performance Using Two Configurations to Remove Arsenic}

After the plant was built, with two units of $25.24 \mathrm{~L} \cdot \mathrm{s}^{-1}$ each, the company ECO-TEC, Water Treatment Systems of Guatemala, Guatemala, operated the treatment process. The evaluation of the plant operation was conducted by the Mexican Institute of Water Technology (IMTA) during two 10-day periods. The water wells' quality was the same for these two periods. The first evaluation period took place in 2008 with ceramic filter media and horizontal flow sedimentation (configuration A [29]), and the second in 2010 with clinoptilolite filter media and high-rate sedimentation (configuration B [30]). Based on the Jar Test, the operational conditions related to the highest arsenic removal were selected: pre-oxidation with $\mathrm{NaOCl}$ (dosage of $4.95 \mathrm{mg} \cdot \mathrm{L}^{-1}$ to maintain a free chlorine residual of approximately $1.0 \mathrm{mg} \cdot \mathrm{L}^{-1}$ for the plant's treated water), ferric chloride dosage of $10-12 \mathrm{mg} \cdot \mathrm{L}^{-1}\left(61.7-74.0 \mu \mathrm{mol} \cdot \mathrm{L}^{-1}\right), \mathrm{pH}$ adjustment of $\sim 6.6-7.0$ and without clay.

Table 6 presents the average values for $\mathrm{pH}$, true color, iron and arsenic (V) resulting from the arsenic removal process. The operating conditions of configurations A and B were described in Tables 3 and 4 of the methodology. The $\mathrm{pH}$ was maintained at a level between 6.84 and 7.23 for both configurations. True color removal was $77.53 \%$ for configuration A and $89.54 \%$ for configuration B, due to the dosage of MIT3 polymer.

Table 6. Results of the evaluation of the NCMG plant.

\begin{tabular}{|c|c|c|c|c|c|c|c|c|}
\hline \multirow[b]{2}{*}{ Process Water } & \multicolumn{4}{|c|}{ Configuration A, Ceramic Filter } & \multicolumn{4}{|c|}{ Configuration B, Clinoptilolite Filter } \\
\hline & pH & $\begin{array}{c}\text { Color } \\
(\text { UPt-Co) }\end{array}$ & $\begin{array}{c}F_{e_{\text {total }}} \\
\left(\mathrm{mg} \mathrm{L}^{-1}\right)\end{array}$ & $\begin{array}{c}\operatorname{As}(V) \\
\left(\mathrm{mg} \cdot \mathbf{L}^{-1}\right)\end{array}$ & pH & $\begin{array}{c}\text { Color } \\
\text { (UPt-Co) }\end{array}$ & $\begin{array}{c}F_{e_{\text {total }}} \\
\left(\mathrm{mg} \cdot \mathrm{L}^{-1}\right)\end{array}$ & $\begin{array}{c}\operatorname{As}(V) \\
\left(m g \cdot L^{-1}\right)\end{array}$ \\
\hline Raw water & 7.23 & 17.8 & 0.72 & 0.092 & 6.98 & 35.0 & 1.48 & 0.171 \\
\hline $\begin{array}{l}\text { Raw water }+ \\
\text { Fe(III) dosage }\end{array}$ & - & - & 2.78 & - & - & - & 3.96 & - \\
\hline Settled water & 7.08 & 37.8 & 1.96 & 0.038 & 6.84 & 6.33 & 0.75 & 0.028 \\
\hline Unfiltered water & 7.13 & 55.4 & 2.18 & 0.068 & 7.10 & 12.33 & 0.88 & 0.019 \\
\hline Filtered water & 7.22 & 4.0 & 0.56 & 0.026 & 7.12 & 3.66 & 0.35 & 0.015 \\
\hline
\end{tabular}

Average treated water turbidity varied between 0.23 and 1.38 NTU because the well pumps were regulated by the water levels in the storage tanks, which depended on household consumption. Therefore, the pumps stopped working $4 \mathrm{~h}$ per day, producing an accumulation of solids in the water tanks' reservoirs and, thus, producing variations in turbidity. Filtered water turbidity in the filters was below 1 NTU, which complies with the standard. The manganese concentration in the treated water was $<0.05 \mathrm{mg} \cdot \mathrm{L}^{-1}$ and total and fecael coliforms were absent.

Figures 9 and 10 show the removal of iron and arsenic for configurations $\mathrm{A}$ and $\mathrm{B}$. The best results were obtained with configuration $\mathrm{B}$, in which the dosage of $\mathrm{NaOH}$ decreased from 22.78 to $13.90 \mathrm{mg} \cdot \mathrm{L}^{-1}$, resulting in a decrease in raw water $\mathrm{pH}$ from 7.23 to 6.98 , for a better coagulation and flocculation process. The $\mathrm{pH}$ was relatively stable during operations, between 6.84 and 7.22. A second polymer was dosed, MIT03, to remove color that appeared due to the dosage of ferric chloride; $81.91 \%$ was removed in the settled water. Finally, CH-polyfocal coagulant was dosed at $1.8 \mathrm{mg} \cdot \mathrm{L}^{-1}$ to form flocs, with better sedimentation characteristics. 
Figure 9. Iron removal in full-scale NCMG plant for configurations A and B.

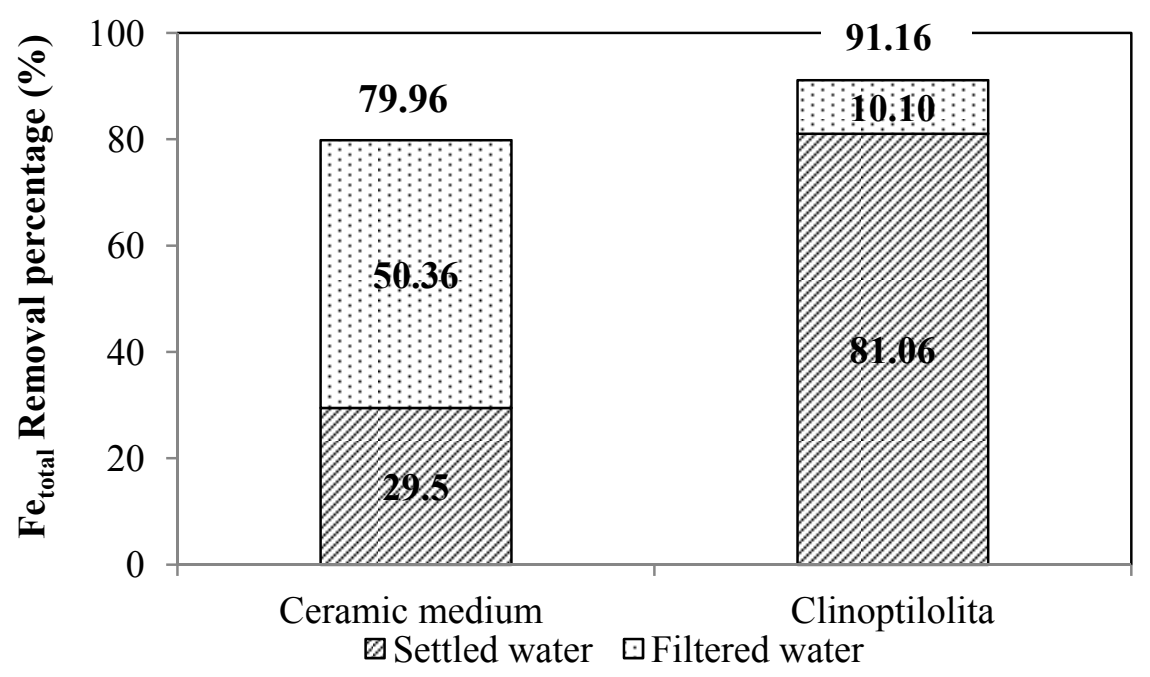

Figure 10. Arsenic (V) removal in full scale NCMG plant with ferric chloride for configurations $\mathrm{A}$ and $\mathrm{B}$.

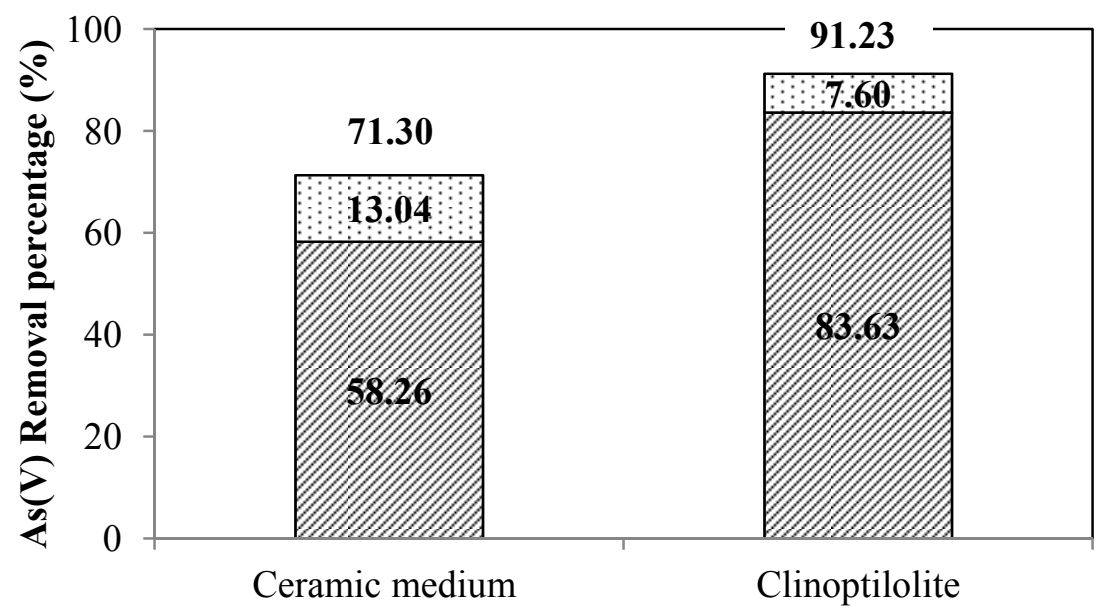

$\square$ Settled water $\square$ Filtered water

The increased surface charge from $72.2 \mathrm{~m}^{3} \cdot \mathrm{m}^{-2} \cdot$ day $^{-1}$ (configuration A) to $150 \mathrm{~m}^{3} \cdot \mathrm{m}^{-2} \cdot$ day $^{-1}$ (configuration B) and the load on the overflow from 2.31 to $3.67 \mathrm{~L} \cdot \mathrm{m}^{-1} \cdot \mathrm{s}^{-1}$ resulted in a greater efficiency in the removal of iron and arsenic (V) in the settled water, from $29.5 \%$ to $81.06 \%$ and from $58.26 \%$ to $83.63 \%$, respectively (Figures 9 and 10 ). In respect to the iron removal in the filtered water, $50.36 \%$ is observed in the ceramic filter (Figure 9), which is higher than the $10.10 \%$ obtained with the clinoptilolite filter. The first high value was due to a low iron removal in the low-rate sedimentation basin for configuration A. This same behavior was reflected in the removal of arsenic (V) $13.04 \%$ for the ceramic and $7.60 \%$ for clinoptilolite media.

The loading capacity of the medium for clinoptilolite is up to 1.5 times greater than that (ceramic synthetic media) and up to 2.8 times greater than the capacity of sand filters. This results in longer run times with less frequent backwashing, providing significant water savings. The filters were backwashed when the first of the following occurred: filter head loss reached approximately 50 psi of 
pression, the filtered water turbidity reached approximately 2.5 NTU or the filter length of run approached $16 \mathrm{~h}$.

In addition to being a filter media, clinoptilolite is an adsorbent and ion exchanger. An example of zeolites is greensand, which is a granular material composed of mineral glauconite. It has been coated with manganese oxide. Studies by Garrido [31] with a full-scale filter, flow of $15 \mathrm{~L} \cdot \mathrm{s}^{-1}$, a filtration rate of $21 \mathrm{~m}^{3} \cdot \mathrm{m}^{-2} \cdot \mathrm{h}^{-1}$, contact time of $2.54 \mathrm{~min}$ and $\mathrm{Fe}(\mathrm{III})$ dosing of $15.99 \mathrm{mg} \cdot \mathrm{L}^{-1}\left(286.24 \mathrm{~mol} \cdot \mathrm{L}^{-1}\right)$ resulted in $84.3 \%-87.0 \%$ removal of $\mathrm{As}(\mathrm{V})$, with an initial concentration of arsenic between 0.070 and $0.085 \mathrm{mg} \cdot \mathrm{L}^{-1}$.

In practice, removal efficiency can depend on the efficiency of the solid-liquid separation process. Filtration must be effective so as to avoid increased arsenic concentrations in treated water caused by the breaking up of colloidal particles, which may be associated with arsenic.

In addition to the factors influencing the efficient removal of arsenic from water by iron hydroxides, the ratio of Fe-As must be taken into account.

Figure 11 shows a plot of the Fe-As ratio, where a good correlation with plant operations can be seen. Results show that, most of the time, operations can lower the NCMG average arsenic content of the water in the wells $80.96 \%$, to $1: 46$ of the original concentrations (Figures 11 and 12). A general guideline is $1 \mathrm{mg} \cdot \mathrm{L}^{-1}$ of ferric chloride to remove $0.020 \mathrm{mg} \cdot \mathrm{L}^{-1}$ of arsenic (ratio 1:50). This can vary greatly depending on $\mathrm{pH}$, silica and other competing ions in the water.

Studies by Dahi and Liang [32] about the use of naturally occurring iron precipitates in ground water in Bangladesh have demonstrated that $65 \%$ of the hand tubewell water contains iron in excess of $2 \mathrm{mg} \cdot \mathrm{L}^{-1}$, and in many areas with acute problems with iron, the concentration of dissolved iron is higher than $15 \mathrm{mg} \cdot \mathrm{L}^{-1}$. Although no good correlation between concentrations of iron and arsenic has been determined, iron and arsenic have been found to co-exist in ground water.

Figure 11. Correlation between Fe doses and As removal in full-scale NCMG plant.

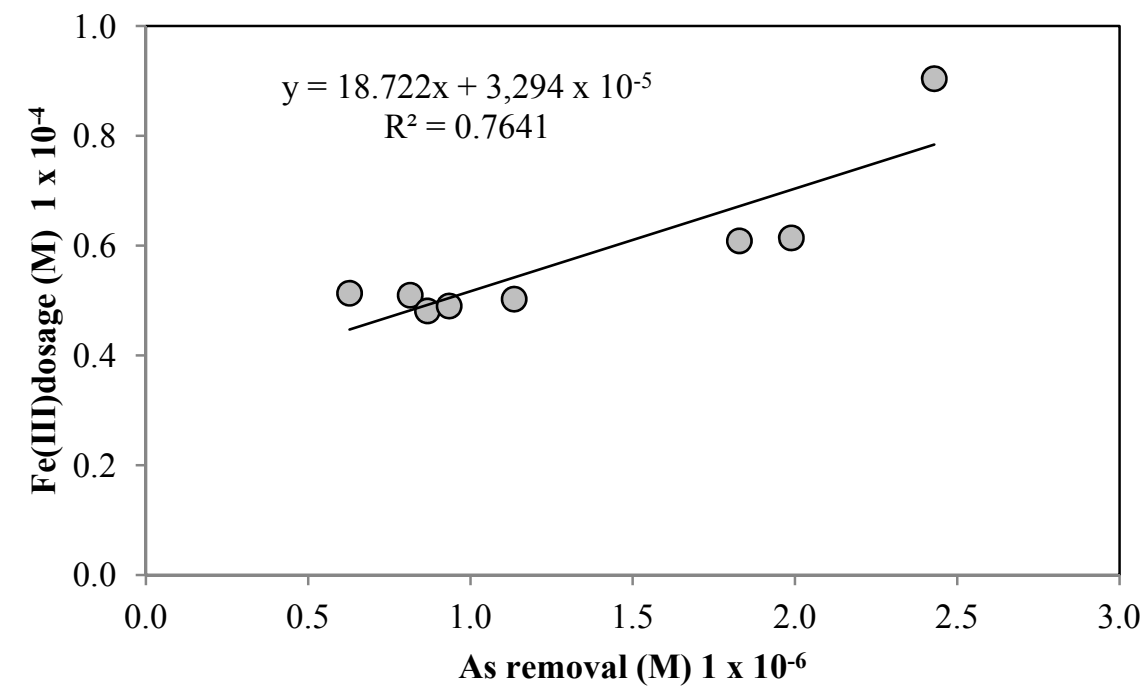


Figure 12. Correlation between experimental and theoretical Fe(III) and As removal in full-scale NCMG plant.

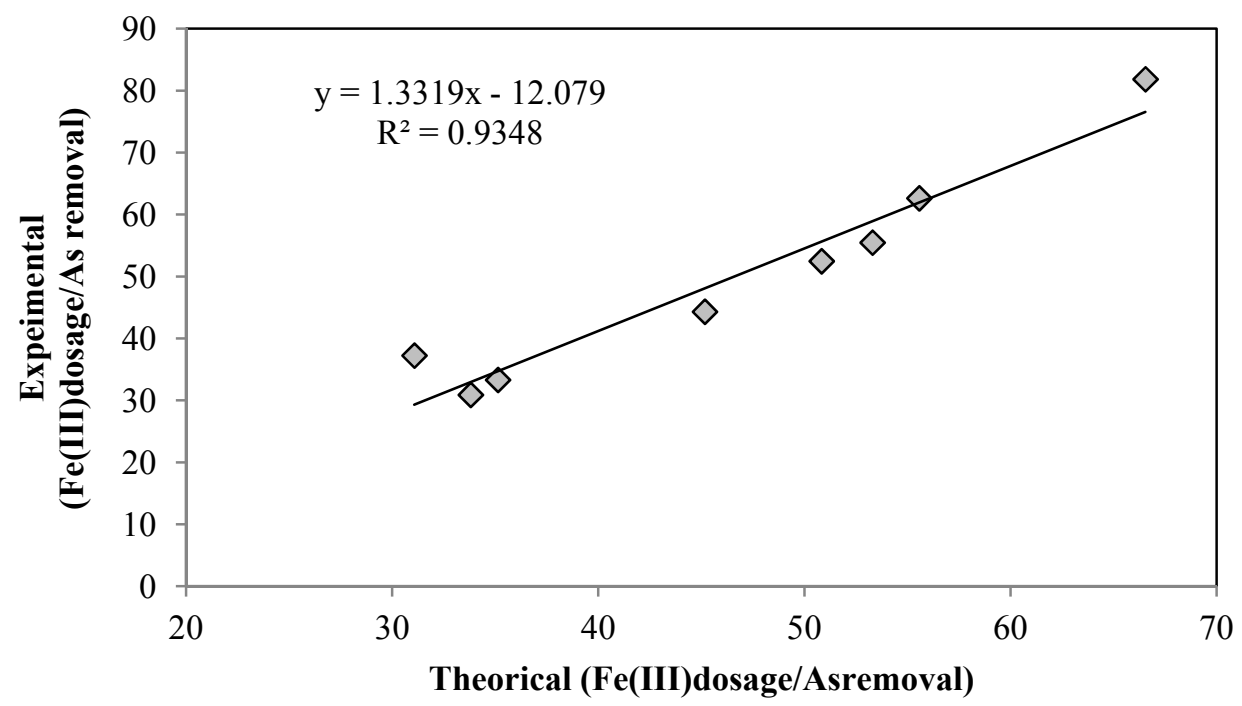

By simplifying the linear isotherm [Equation (1)], the removal of $\mathrm{As}(\mathrm{V})$ by adsorption-coprecipitation on iron hydroxides in the coagulation treatment plants can be described as:

$$
\text { As adsorbed } \%=\text { As removal } \%\left(\frac{\mathrm{K}[\mathrm{Fe}]}{1+\mathrm{K}[\mathrm{Fe}]}\right)
$$

where As adsorbed \%: Arsenate removed from the solution by iron hydroxide; [Fe]: Concentration of iron hydroxide formed (mM); K: Cte adsorption characteristic, having a value of $\mathrm{K}=78 \mathrm{mM}^{-1}$ for coagulation treatment plants; As adsorbed for configuration A: 56.37\%; As adsorbed for configuration B: $77.10 \%$; It is assumed that all dosed iron becomes an insoluble precipitate.

In addition, the Environmental Protection Agency (EPA) has developed a toxic characteristic leaching procedure (TCLP) test to identify wastes likely to leach toxic chemicals into groundwater [33]. The permissible level for TCLP leachate is generally 100 times higher than the maximum contaminant level for drinking water. In this study, $6.6-15.6 \mathrm{mg} \cdot \mathrm{L}^{-1}$ was found for leached arsenic, whereas the acceptable Guatemalan level in drinking water is $0.010 \mathrm{mg} \cdot \mathrm{L}^{-1}$. Sludge leaching more than $5 \mathrm{mg} \cdot \mathrm{L}^{-1}$ of arsenic would be considered hazardous and would require disposal in a special hazardous waste landfill. The sludge produced in the NCMG plant is disposed of in special confinement.

Finally, the cost of treatment for arsenic removal at the NCMG plant was calculated, taking into account the quantity of treated water, reactive, use per day and power per day. Total cost of treatment was USD $0.16 \mathrm{~m}^{-3}$ for configuration A and USD $0.113 \cdot \mathrm{m}^{-3}$ for configuration B.

\section{Conclusions}

International concern has been focused on the problem of arsenic in groundwater in developing countries because of large populations that are adversely affected by high arsenic concentrations. Arsenic removal studies conducted at the full-scale NCMG plant demonstrated that the best results were obtained for configuration B (clinoptilolite filter), with $96.80 \%$ arsenic removal from treated 
water, resulting in $0.005 \mathrm{mg} \cdot \mathrm{L}^{-1}$, a value which complies with Guatemala's water quality standard COGUANOR NGO $29001: 99\left(0.010 \mathrm{mg} \cdot \mathrm{L}^{-1}\right)$. The factors that influence the effective removal of arsenic by iron hydroxides are the hydraulic configuration of the processing units, type of filter media and dosage of reagents at a suitable Fe-As ratio. The efficiency of arsenic removal can be increased by increasing the dosage of the coagulant and the addition of polymer. Comparable trends observed in studies of arsenic adsorption on hydrous metal oxides confirm that adsorption is an important (though not sole) process in arsenic removal during coagulation. For clinoptilolite, filtration is the principal process used in the removal of arsenic because of higher adsorption-coprecipitation for arsenic removal by iron hydroxides $(70.68 \%-77.10 \%)$ with the coagulation process.

\section{References}

1. Tseng, W. Effects and dosage-response relationships of skin cancer and blackfoot disease with arsenic. Environ. Health Perspect. 1977, 19, 109-119.

2. Kumar-Mandal, B.; Suzuki, T. Arsenic round the world: A review. Talanta 2002, 58, 201-235.

3. Farias, S.; Casa, V.; Vazquez, C.; Ferpozzi, L.; Pucci, G.; Cohen, I. Natural contamination with arsenic and other trace elements in ground waters of Argentine Pampean Plain. Sci. Total Environ. 2003, 309, 187-199.

4. World Health Organization (WHO). Verification of Arsenic Mitigation Technologies and Field Test Methods. In Proceedings of Intercountry Consultation, Kolkata, India, 9-12 December 2002; WHO Regional Office for South-East Asia: New Delhi, India, 2004.

5. Bundschuh, J.; Litter, M.; Ciminelli, V.S.T.; Morgada, M.E.; Cornejo, L.; Hoyos, S.G.; Hoinkis, J.; Alarcon-Herrera, M.T.; Armienta, M.A.; Bhattacharya, P. Emerging mitigation needs and sustainable options for solving the arsenic problems of rural and isolated urban areas in Latin America-A critical analysis. Water Res. 2010, 44, 5828-5845.

6. Garrido, S.; Avilés, M.; Ramírez, A.; Calderón, C.; Ramírez-Orozco, A.; Nieto, A.; Shelp, G.; Seed, L.; Cebrian, M.; Vera, E. Arsenic Removal from Water of Huautla, Morelos, Mexico Using Capacitive Deionization. In Proceedings of the International Congress on Natural Arsenic in Groundwaters of Latin America, Mexico City, Mexico, 20-24 June 2006; pp. 665-676.

7. Amy, G.; Edwards, M.; Brandhuber, P.; McNeill, L.; Benjamin, M.; Vagliasindi, F.; Carlson, K.; Chwirka, J. Arsenic Treatability Options and Evaluation of Residuals Management Issues; 90771; American Water Works Association: Denver, CO, USA, 1999.

8. Environmental Protection Agency (EPA). Technologies and Costs for Removal of Arsenic from Drinking Water; EPA 815-R-00-028; Environmental Protection Agency: Washington, DC, USA, 2000.

9. Shen, Y.S. Study of arsenic removal from drinking water. J. Am. Water Works Assoc. 1973, 65, 543-547.

10. Ahmed, K.; Bhattacharya, P.; Hasan, M.; Akhter, S.; Alam, S.M.; Bhuyian, M.A.; Imam, M.B.; Khan, A.; Sracek, O. Arsenic enrichment in groundwater of the alluvial aquifers in Bangladesh: An overview. Appl. Geochem. 2004, 19, 181-200.

11. Pande, S.P.; Deshpande, L.S.; Patni, P.M. Arsenic removal studies in some ground waters of West Bengal, India. J. Environ. Sci. Health 1997, A32, 1981-1987. 
12. Petkova, V.; Rivera, L.; Aviles, M.; Piña, M.; Martin, A. Remoción de Arsénico de Agua Para Consumo Humano; Reporte final; Instituto Mexicano de Tecnología del Agua, Jiutepec, Mexico, 1997.

13. Ngo, H.; Vigneswaran, S.; Hu, J.; Thirunavukkarasu, O.; Viraraghavan, T. A comparison of conventional and non-conventional treatment technologies on arsenic removal from water. Water Sci. Technol. Water Supply. 2002, 2, 119-125.

14. Gulledge, J.H.; O'Connor, J.T. Removal of arsenic(V) from water by adsorption on aluminum and ferric hydroxides. J. Am. Water Works Assoc. 1973, 65, 548-552.

15. Sorg, T.J.; Logsdon, G.S. Treatment technology to meet the interin primary drinking water regulations for inorganics: Part 2. J. Am. Water Works Assoc. 1978, 70, 379-393.

16. Logsdon, G.S.; Sorg, T.J.; Symons, M. Removal of Heavy Metals by Conventional Treatment. In Proceedings of the 16th Water Quality Conference; College of Engineering, University of Illinois, Urbana-Champaign, IL, USA, 12-13 February 1974; Volume 71, No. 108; pp. 111-133.

17. Instituto Nacional de Estadística (INE). Anuario Estadístico de Guatemala; Instituto Nacional de Estadística, Guatemala, Guatemala, 2002.

18. Cebrián, M.E.; Albores, A.; García-Vargas, G.; Del Razo, L.M. Chronic Arsenic Poisoning in Humans: The Case of Mexico. In Arsenic in the Environment. Part II: Human Health and Ecosystem Effects; Wiley Interscience: New York, NY, USA, 1994; pp. 94-97.

19. American Society for Testing and Materials (ASTM). Standard Practice for Coagulation-Flocculation Jar Test of Water E1-1994 R(1995), D 2035-80; Annual book of ASTM standards; ASTM International: Whashington, DC, USA; Volume 11.02, 1995.

20. Arboleda, J. Teoría y Práctica de la Purificación del Agua, 3th ed.; Arboleda Valencia, J., Ed.; Mac Graw Hill.: Bogotá, Colombia, 2000; pp. 169-170.

21. Environmental Protection Agency (EPA). Removal of Arsenic in Drinking Water. Kinetico ${ }^{\circledR}$ Incorporated Macrolite Coagulation and Filtration System; Model CPS100CPT, 2001. NSF 01/23EPADW395; Environmental Technology Verification Report; Environmental Protection Agency: Washington, DC, USA, 2001.

22. Standard Methods for Examination of Water and Waste Water, 20th ed.; American Public Health Association: New York, NY, USA, 1998.

23. HACH ${ }^{\mathrm{TM}}$ Company. Procedures Manual DR/2010, Spectrophotometer; HACH Company: Loveland, CO, USA; 1998.

24. Erickson, B.E. Fields kits fail to provide accurate measure of arsenic in groundwater. Environ. Sci. Technol. 2003, 1, 35-38.

25. Scott, K.N.; Green, J.F.; Do, H.D.; McLean, S.J. Arsenic removal by coagulation. J. Am. Water Works Assoc. 1995, 87, 114-126.

26. Chen, H.W.; Frey, M.M.; Clifford, D.; McNeill, L.S.; Edwards, M. Arsenic treatment considerations. J. Am. Water Works Assoc. 1999, 91, 74-85.

27. Hering, J.G.; Chen, P.Y.; Wilkie, J.A.; Elimelech, M. Arsenic removal from drinking water during coagulation. ASCE J. Environ. Eng. 1997, 123, 800-807.

28. Laky, D.; László, B.; Licskó, I. Effects of several water quality parameters on arsenic removal by coagulation: Laboratory experiments and a pilot-scale study. Water Pract. Tecnol. 2008, 3, 1-8. 
29. Garrido Hoyos, S.E. Análisis de la información técnica y evaluación del funcionamiento de la planta para remover arsénico, Mixco, Guatemala. Informe final; Instituto Mexicano de Tecnología del Agua, Jiutepec, México, 2008; p. 125.

30. Garrido Hoyos, S.E. Seguimiento del funcionamiento de la planta convencional con filtración kinetico para remoción de arsénico y capacitación de personal en el funcionamiento de la planta, Mixco, Guatemala. Reporte final; Instituto Mexicano de Tecnología del Agua, Jiutepec, México, 2010; p. 72.

31. Garrido, S.; Piña, M.; López, I.; De La O, D.; Rodríguez, R. Behavior of two filters media for to remove arsenic from drinking water. Filtration 2013, 13, 21-26.

32. Dahi, E.; Liang, Q. Arsenic Removal in Hand Pump Connected Iron Removal Plants in Noakhali, Bangladesh. In Proceedings of the International Conference on Arsenic Pollution of Ground Water in Bangaldesh: Causes, Effect and Remedies, Dhaka, Bangladesh, 8-12 February 1998.

33. Eriksen-Hamel, N.; Zinia, K.N. A Study of Arsenic Treatment Technologies and Leaching Characteristics of Arsenic Contaminated Sludge. In Technologies for Arsenic Removal from Drinking Water; Ahmed, M.F., Ali, M.A., Adeel, Z., Eds.; Bangladesh University of Engineering \& Technology and United Nations University: Dhaka, Bangladesh, 2001; pp. 207-213.

(C) 2013 by the authors; licensee MDPI, Basel, Switzerland. This article is an open access article distributed under the terms and conditions of the Creative Commons Attribution license (http://creativecommons.org/licenses/by/3.0/). 